\title{
Comparative Study on Physical Activity and Back Pain of Young Mothers in Some Eastern European Countries
}

Authors' contribution:

A) conception and design of the study

B) acquisition of data

C) analysis and interpretation of data

D) manuscript preparation

E) obtaining funding

\author{
Barbara Abonyi \\ Semmelweis University in Budapest, Hungary
}

\section{ABSTRACT}

Young mothers frequently complain of backaches. The aim of this paper is to reveal if there is any relationship between physical activity in their early years (aged 6-18 years) and in adulthood, and between current physical activity and back pain. The paper is based on empirical research carried out by the survey method. With the help of structured sampling, 336 young mothers, all within 1-3 years after giving birth and all of whom were from the V4 countries and Romania, were included in the study. Their early and present physical activities, as well as their back pain in the upper and lower part of the back, was examined. Data were collected by questionnaire. To process the data, SPSS.17 was used. The results show that young mothers who were the most physically active in their early years remained the most active as adults. The correlation between the young mothers' sporting activity in the early years (aged 6-18 years) and adulthood is strong. Due to their activity, the most physically active young mothers have less upper and lower back pain. The connection between current sporting activity and back pain were also significant both by the upper and the lower part of the back. It is concluded that regular physical activity in childhood is often continued and make up part of a young women's life. As a result, they bear the early period of motherhood fitter and with fewer backaches.

young mothers, physical activity, childbirth, back pain

KEYWORDS

\section{Introduction}

Although more than 20 years have passed since the 1989-1990 political regime change, a number of facts reflect nowadays that the ex-socialist countries have similar pasts. One of the common factors is that between 1995 and 2004, several fast growing cities (Budapest, Bucharest, Prague, and Warsaw) were seen in former communist states, and there were no major differences in the nature of their development (Jeney, 2008). Another interesting fact is mirrored by the findings of an international comparative study. Quality of life was examined by the UNDP (United Nations Development Program) in more than 150 countries. Country ranking is indicated by the Human Development Index. In 2002, this ranking placed Czech Republic $33^{\text {rd }}$, Hungary $35^{\text {th }}$, Slovakia $36^{\text {th }}$, and Poland $37^{\text {th }}$. This data also support our conviction that it is relevant to 
compare social problems in these post-communist countries (Bendíková et al., 2011).

The role of women has also changed considerably in this region in the last 20 years. One of the consequences of this is shown by the growing age of becoming a mother. For instance, in Hungary in 1990 women were aged 23 years on average at the time of their first childbirth, in 2000 they were 25 year old, and in 2008 they were 28 year old. The major reason for this trend is that young people study longer and they prolong their youth. They prefer to undertake at an older age the problems, the tasks, and the difficulties of adulthood.

To have a baby means sacrifice from both the social and physical perspective. Among the physical difficulties, backache is considered a common problem. The course of pregnancy causes increased problems with the back (Toldy, 2009). Childbirth, followed by holding and carrying the baby, can exacerbate back pain. According to Murtezani et al. (2011), among industrial workers trunk flexion and lifting of loads, both $<25 \mathrm{~kg}$ and $>25 \mathrm{~kg}$, were risk factors for getting low back pain. So this period (1-3 years following childbirth) is suitable for demonstrating how physical activity has an effect on back pain, one of the most prevalent contemporary health problems.

The major aim of this paper is to reveal whether there is any relationship between young mothers' physical activity in their early years (aged 6-18 years) and in their adulthood, and between their current physical activity and their back pains. These issues are examined among Czech, Hungarian, Polish, Romanian, and Slovakian young mothers. An additional aim of this article is to compare the main differences and similarities between the young mothers of different nationalities in this respect. The neglecting of the mass sport/leisure sport in these post-communist states was the reason for selecting the research population from these countries.

According to the findings of recent research carried out in this region, precisely in Hungary (Gal, 2008), the higher one's qualification and the more developed the town or outskirts one lives in, the more frequently one is engaged in physical activity. Further, women are more active in recreational sports, and they lead more physically active lifestyles than men. Taking into consideration that in contemporary postsocialist countries, the most physically active groups consist of urban, well-educated women, we chose the research population from large cities in each country and selected well-educated young mothers.

\section{Sporting heritage in the former Eastern bloc}

The former socialist countries were under the control of the Soviet Union. International sport competitions were used to demonstrate the superiority of socialism over capitalism. Kobiela (2011) quotes one of Orwell's sayings: "International sport is war without shooting". For the aforementioned reasons, elite sport was supported by the state even under the worst economic conditions; however, sport for the general public, leisure, school, and university were treated poorly (Foldesi, 2011; Gal, 2011).

Following the 1989-1990 political transition in the Eastern bloc, radical changes occurred in all areas of life in these countries. New ideologies, values, and opportunities came to the fore. The winds of change also affected sport as a social sub-system, and it was necessary to reconstruct it (Slepicková, 2011; Sekot, 2011a). The period when the ruling party preferred the interests of the State to those of the citizens ended; sporting organizations could again be independent from central control. However, the political regime change led to other difficulties, such as a lack of resources.

According to Foldesi (1993), the fact that sport, following the introduction of the socialist system, has been nationalized in a broader sense, and was centrally planned, directed and monitored for four decades, made both society and professionals working in sport almost completely forget that sport is originally a product of civil society. 


\section{Physical activity and health in the countries involved in the research}

\section{Hungary}

In Hungary, "sport as a social institution is still seeking its place in society" (Foldesi, 2011, p. 61). The inactivity trend resulted in the population's poor health. From the morbidity tables published by the Special Eurobarometer (2007), the unfavorable data in connection with frequent occurrence of hypertension (45\% treated), diabetes, ischemic heart disease, locomotive disorders (36\% treated), and mental disorders illustrate that the state of health of the Hungarian population lags behind the other countries of the European Union (Gal, 2008). Regarding healthy nutrition and self-evaluation of health, better education correlates to better health.

Concerning physical activity: $26 \%$ of the Hungarian population does some physical activity daily; $13 \%$ does some physical activity 2-3 times a week, and 30\% does some physical activity irregularly. In total, $32 \%$ of the Hungarian population is not physically active at all. There is no major difference between the two genders in Hungary as regards readiness to participate in sport (Gal, 2008). Considering the motivations for being active physically, the protection of health is mentioned in first place; aesthetic considerations are second. The main reasons for not being active physically are lack of time, lack of money, health problems, or simply a dislike of exercise (Gal, 2008).

In Hungary the percentage of smokers is 36\%. (Egészségügyi Minisztérium, 2009) The GDP: USD 129.9 billion (2011, estimated) (Global Finance, 2012).

Family support information: Maternity support and paid leave is available until the child is three years old; mothers are not required to return to employment until the child is one year old (MEDINFO, 2004).

\section{Romania}

In this country, the leading reasons for mortality are vascular lesion, respiratory problems, and ischemic heart disease (Egészségügyi Stratégiai Kutatóintézet, 2010). More than half of the citizens have hypertension (Special Eurobarometer, 2007). In the early 2000s, almost one-sixth of the male population and one-fourth of the female population were obese (Domnariu \& Furtunescu, 2011). About one-third of Romanians suffer from chronic disorders of muscles, bones, or joints (rheumatism, arthritis) (Special Eurobarometer, 2007).

The percentage of smokers is 36\% (Egészségügyi Minisztérium, 2009).

Family support information: After childbirth, maternity leave is available for two years. Maternity support is available for four children. Every child up to the age of 18, or until graduation from secondary school, is eligible for child benefits (EUvonal, 2012).

The GDP is USD 186.4 billion (2010, estimated)(Global Finance, 2012).

\section{Slovak Republic}

The division of Czechoslovakia into Czech Republic and Slovakia happened on January 1, 1993. Since then, positive changes can be observed in several areas of social life, but the population's health has not improved at all.

The leading reasons of mortality are cardiovascular lesion and malignant tumors (Egészségügyi Stratégiai Kutatóintézet, 2006). The statistics for both illnesses are higher than the European average. According to Bendíkova (2011), in Slovakia three fouths of the adult women and more than the half of the adult men (up to the age of 70) suffer from joint pain and headache. Back pain affects $50-80 \%$ of the adult population. Circulatory disorders are characteristic of females; males typically suffer from high blood pressure. Moreover, about the half of the population suffers from hypertension.

The Slovakian population's contemporary lifestyle is responsible for the gradually increasing 
morbidity, due to smoking, a lack of physical activity, stress, and bad eating habits.

As for physical activity: $48 \%$ of men and $52 \%$ women admit to not engaging in physical activity regularly, the dominant forms of which are working in a garden and walking.

The percentage of smokers is 36\% (Egészségügyi Minisztérium, 2009); one-fourth of women are smokers; and the percentage of young smokers (aged 15-29 years) has increased to 52\% (Bendíkova et al., 2011).

Family support information: The duration of maternity leave and support is usually 28 weeks. Further social support is available until the child is 3 years old (EUvonal, 2012).

The GDP is USD 94.5 billion (2011, estimated) (Global Finance, 2012).

\section{Czech Republic}

Increasing frequency of civilization disorders is prevalent in Czech Republic: $41 \%$ of the population suffers from hypertension and $25 \%$ of the population suffers from chronic muscle, bone, and joint disorders (rheumatism, arthritis). (Special Eurobarometer, 2007). In the group aged 20-65 years, two-thirds of the men and more than half of the women are overweight or obese.

In connection with physical activity, Sekot (2011b) refers to several surveys that demonstrate the aversion or the inability of the majority of Czechs to regularly practice sport. Sport participation is instead regarded as a fashionable activity and not as an integral part of everyday lifestyle. People prefer to watch sport rather than participating in it. Complete inactivity characterizes a large proportion of the population. Women do sport less regularly (22.7\%) compared to men (14.6\%). The reasons given for the sedentary lifestyle are mainly related to lack of time as well as to financial and organizational problems (Sekot, 2011).

The leading reasons of mortality in this country are cardiovascular lesions (50.2\%), malignant tumors, and respiratory diseases. About one-third of the population is smokers (Egészségügyi Minisztérium, 2009).

Family support information: Maternity support is granted until the child is 4 years old. It is the parents' choice whether financial support is provided for two, three, or four years. The parents might have a job throughout this period, but they must organize childcare (EUvonal, 2012).

The GDP is USD 205.9 billion (2011, estimated) (Global Finance, 2012).

\section{Poland}

In Poland, the main causes of mortality are cardiovascular lesions (46\%) and malignant tumors (Egészségügyi Stratégiai Kutatóintézet, 2011). In total, 29\% of the Polish population suffers from chronic muscle, bone, or joint disorders (rheumatism, arthritis); $45 \%$ suffer from hypertension (Special Eurobarometer, 2007).

The lack of regular physical activity also contributes to Poles' health problems. Based on a CBOS (Centre for Social Opinion Research) survey, Rymarczyk (2011) states that more than half of Poland's citizens do not participate in any physical activity (57\% of the women and $52 \%$ of the men). One-fifth of Poles do physical activity rarely, and only one-quarter of them do it regularly or quite often. As for Polish people's motivations for physical activity, the improvement of health is the main reason. The Sport for All programs have not been very successful. The main reasons for inactivity are: the relative poverty of Polish society, the lack of voluntary activity, and the fact that the majority of government funds are spent on elite sport (Rymarczyk, 2011).

Family support information: Maternity leave is 18 weeks after the first childbirth; then 20 weeks. There is a single maternity benefit following childbirth. Maternity support is available for two years only for those who cease their employment and for those whose household income per capita does not exceed $25 \%$ of the previous year's average income. Family allowance also is available in the case of low monthly household 
income per capita. (EUvonal, 2012)

The GDP is USD 528.4 billion (2011, estimated) (Global Finance, 2012).

\section{Methods}

\section{Population and sample}

We conducted this comparative research in November and December of 2011 and in January and February of 2012. Locations included Hungary in the outskirts of Budapest; in Romania in the outskirts of Târgu Mure and in the outskirts of Sfântu Gheorghe; in the Czech Republic in the outskirts of Prague; in Slovakia in the outskirts of Bratislava and in the outskirts of Komarn; and finally, in Poland in the outskirts of Warsaw and in the outskirts of Wroclaw.

With structured sampling, 336 young mothers were selected. There were two major criteria of the selection: a) young mothers had to be within 1-3 years after giving birth; b) they had to be well educated, and preferably they had to have bachelor's or master's degree, or at least final examination from secondary school .The main characteristics of the sub-samples are the following:

The Czech young mothers $(n=49)$ were aged 29.73 years on average and had an average of 1.44 children. In total, $79.2 \%$ of them had a master's or bachelor's degree, while $20.8 \%$ of them graduated from secondary school.

The Hungarian young mothers $(n=37)$ were aged 34.84 years on average and had an average of 2.21 children. In total, $83.8 \%$ of them had a master's or bachelor's degree, while $16.2 \%$ of them graduated from secondary school.

The Polish young mothers $(\mathrm{n}=29)$ were aged 30.44 years on average and had an average of 1.72 children. In total, $79.3 \%$ of them had a master's or bachelor's degree, while $20.7 \%$ of them graduated from secondary school.

The Romanian young mothers $(n=175)$ were aged 31.75 years on average and had an average of 0.53 children. In total, $88.6 \%$ of them had a master's or bachelor's degree, $10.9 \%$ of them graduated from secondary school, and $0.6 \%$ of them had attended vocational schools.

The Slovakian young mothers $(n=46)$ were aged 30.06 years on average and had an average of 1.58 children. In total, $71.7 \%$ of them had a master's degree or bachelor's degree, while $28.3 \%$ of them graduated from secondary school.

Although all research subjects met the two most important criteria for selection, there were considerable differences among the sub-samples concerning sampling size and the average number of babies the young mothers had in the individual national groups. Therefore, the conclusion drawn from the otherwise important findings of this investigation can be generalized with certain reservations.

\section{Data collection}

The data were collected by questionnaire. Most young mothers were interviewed personally in their own language by a native interviewer. A minority of them answered the questionnaire by means of the Internet. The questionnaire focused on the following areas:

- current status of the young mothers; and who is/was responsible for childcare if they continued working,

- the young mothers' sporting habits in their early years (aged 6-18 years) and 2-3 years before the recent pregnancy,

- the young mothers' current sporting habits and the frequency of their backache(s), if any. 


\section{Treatment of the data}

To process the data, SPSS.17 was used. To analyze the frequency of the answers, descriptive statistics and the $X^{2}$ test were used. To assess significance, the mistake threshold $(\mathrm{p}<0.05)$ was taken as the basis, as it usual in social science research.

\section{Results}

\section{Current status of the young mothers and responsibility for looking after the baby}

In Hungary, $25 \%$ of the young mothers involved in the research sent a child to nursery school. Of these women, $39.3 \%$ work (17.9\% work part-time) after the child is one year old. In Romania, $16.8 \%$ of the young mothers took the baby to nursery (crèche). Of these women, $43.6 \%$ work (18\% work part-time) after the child is one year old. In Slovakia, $61.9 \%$ of the young mothers took a child to nursery. Of these women,

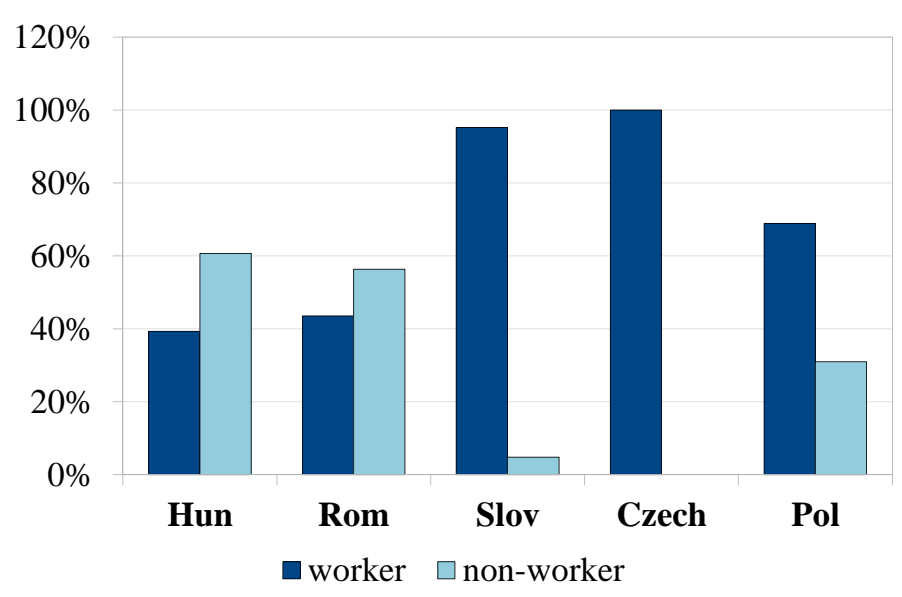
$95.20 \%$ work (23.8\% work part-time) after the child is one year old. In Czech Republic, $77.2 \%$ of the young mothers sent a child to nursery. Of these women, $100 \%(!)$ work (13.6\% work part-time) after the child is one year old. In Poland, $31 \%$ of the young mothers took the baby to nursery. Of these women, $69 \%$ work $(27.6 \%$ work part-time) after the child is one year old (Figure 1).

Figure 1. Young mothers' working status $(\mathrm{N}=336)$

Source: own study.

In all of these countries, those children who do not attend nursery are looked after by a family member. It is not typical to employ a babysitter. These data are consistent with the amount of paid leave available to young mothers in the individual countries. Noticeable differences can be found in the data related to childcare. In Slovakia and Czech Republic, the number of working mothers is substantially higher, as public nurseries are more readily available for childcare than in the other countries involved in our research. The lack of sufficient nurseries can be the main reason for the lower number of working mothers in the other three countries, but mainly in Hungary and in Romania.

\section{Sporting habits in the early years (aged 6-18 years)}

In order to discover the early sporting habits, a retrospective method had to be used. The young mothers were asked whether or not they had been involved in any sporting activity in the early period of their lives - more precisely, between the ages of 6 and 18 years - and if yes, how often: 2-3 times a week, weekly, or monthly. In this paper, the data related to the two extremes, that is, to the most active and to the totally inactive persons, are presented. The findings show that the Hungarian young mothers were the most active in the early period of their lives; nearly half of them practiced some sports 2-3 times per week. The second and third most active group consisted of the Romanian (32\%) and Polish (27.6\%) young mothers; however, they were much less active in this period than were the Hungarians. In their youth, $17.4 \%$ of the Slovakian young mothers and $18.4 \%$ of the Czech young mothers did the optimal amount of physical activity. These differences might be rooted partly in the different school sport systems and partly in the special way the national samples were selected.

On the other hand, the data suggest that $27 \%$ of the Hungarian, $29.7 \%$ of the Romanian, $37.9 \%$ of the Polish, $73.9 \%$ of the Slovakian, and 77,6\% of the Czech young mothers were totally inactive (Figure 2). It has to be emphasized that although these data are relevant to our research, no conclusions can be drawn from 
them regarding children and youth sports in the countries in question.

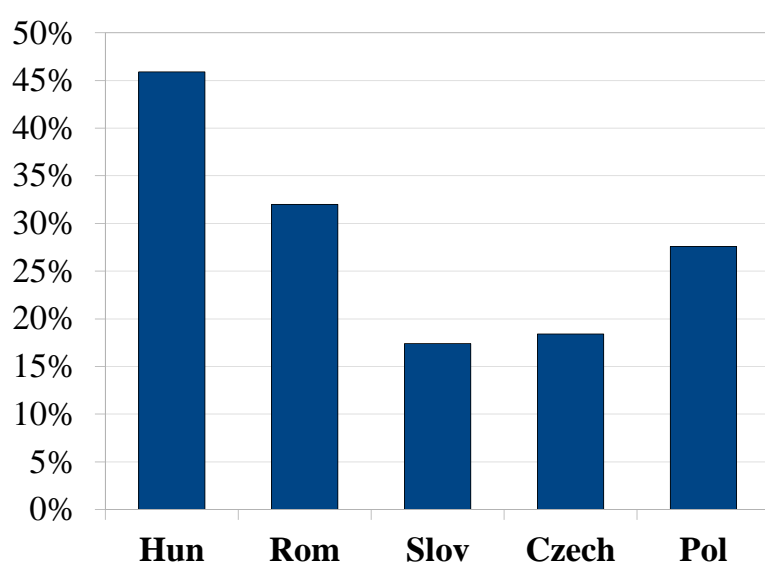

Active 2-3 times a week

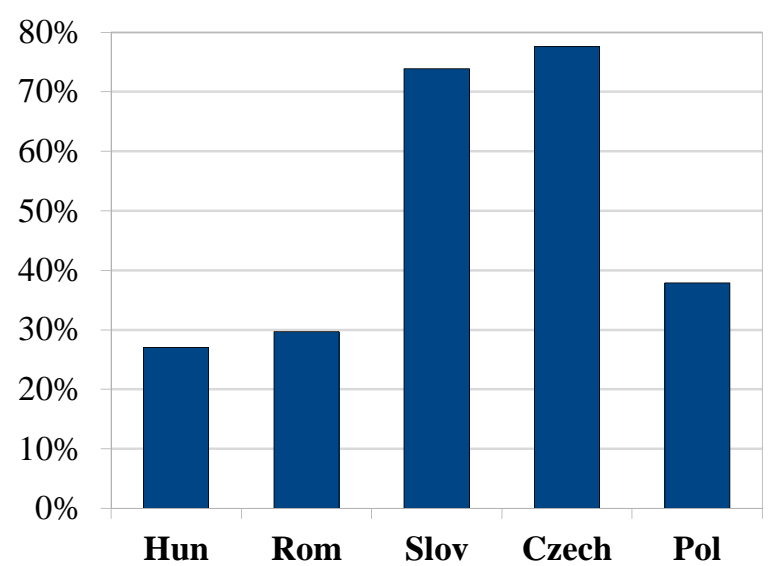

Totally inactive

Figure 2. Young mothers' physical activity in the early years (aged 6-18 years) $(\mathrm{N}=336)$

Source: own study.

\section{Sporting activity 2-3 years before the most recent pregnancy}

According to relevant literature, mothers with one child can organize regular sporting activity for themselves more easily than mothers with more children ( $\mathrm{Gal}, 2003)$. Our research subjects are mainly mothers with one or two children, so before their recent pregnancy they were mainly mothers with one child. Only in Hungary did the research subjects have more than two children on average (2.21). The young mothers were asked how often they practiced any sporting activity two-three years before their most recent pregnancy. In total, $37.8 \%$ of the Hungarian, $14.9 \%$ of the Romanian, $10.9 \%$ of the Slovakian, $18.4 \%$ of the Czech, and $31 \%$ of the Polish young mothers were involved in sport with optimal frequency, which is 2-3 times per week. In this period of their life, almost $50 \%$ of the Hungarian, about $40-40 \%$ of the Polish and the Romanian, nearly $60 \%$ of the Slovakian, and $66 \%$ of the Czech young mothers were totally inactive (Figure $3)$.

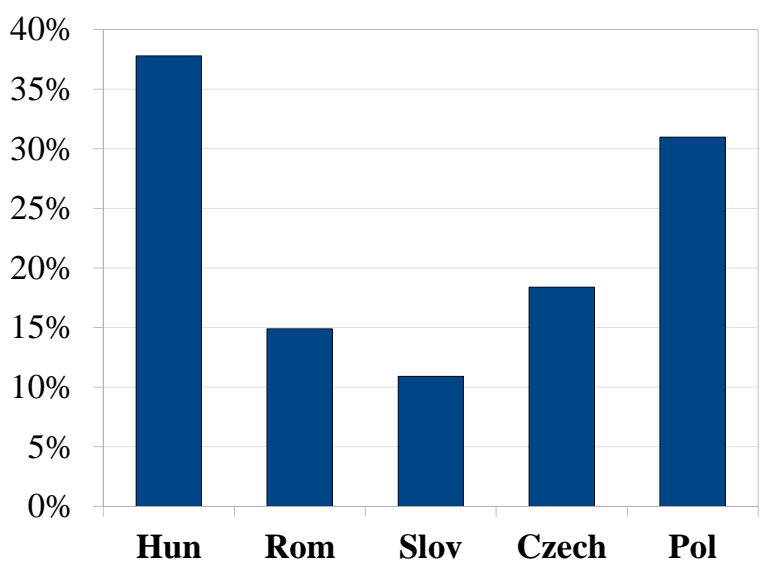

Active 2-3 times a week

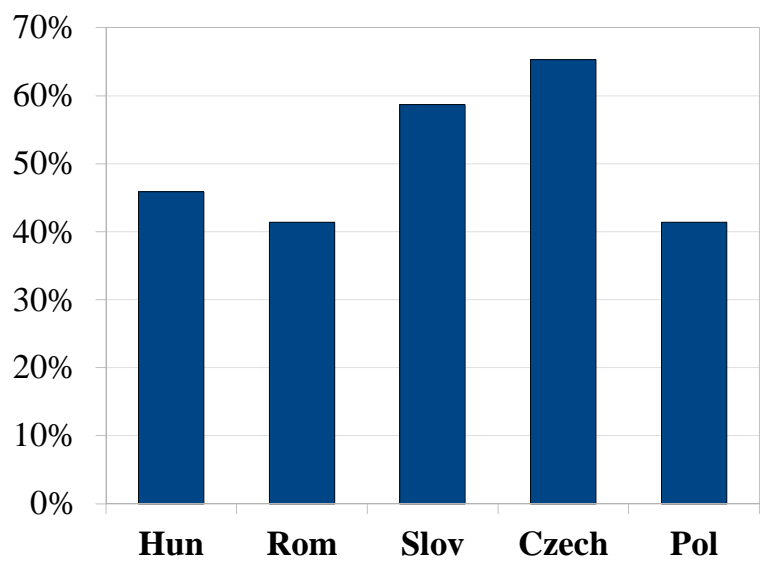

Totally inactive

Figure 3. Young mothers' physical activity two-three years before their most recent pregnancy (N=336)

Source: own study. 
In order to examine the relationship between the frequency of sporting activity in the early years (aged 6-18 years) and in adulthood, cross tabulations were used. The results demonstrate that there is a strong positive correlation between the mothers' physical activity practiced in their early years (aged 6-18 years $)$ and in their adulthood, that is two-three years before their most recent pregnancy $\left(X^{2}=137,541 ; \mathrm{df}=4\right.$; $\mathrm{p}<0.001)$ (Table 1).

Table 1. Physical activity in the early years (aged 6-18 years) and two-three years before the most recent pregnancy

\begin{tabular}{llcccc}
\hline & & \multicolumn{2}{c}{ Physical activity 2-3 years before the most } & Total \\
& & recent pregnancy & peekly & not at all & \\
\hline Physical activity & $2-3$ times/ week & 38 & 40 & 19 & 97 \\
in the early years & weekly & 22 & 50 & 21 & 93 \\
(aged 6-18 years) & not at all & 3 & 22 & 120 & 145 \\
& Total & 63 & 112 & 160 & 335 \\
\hline
\end{tabular}

Source: own study.

\section{Current sporting habits}

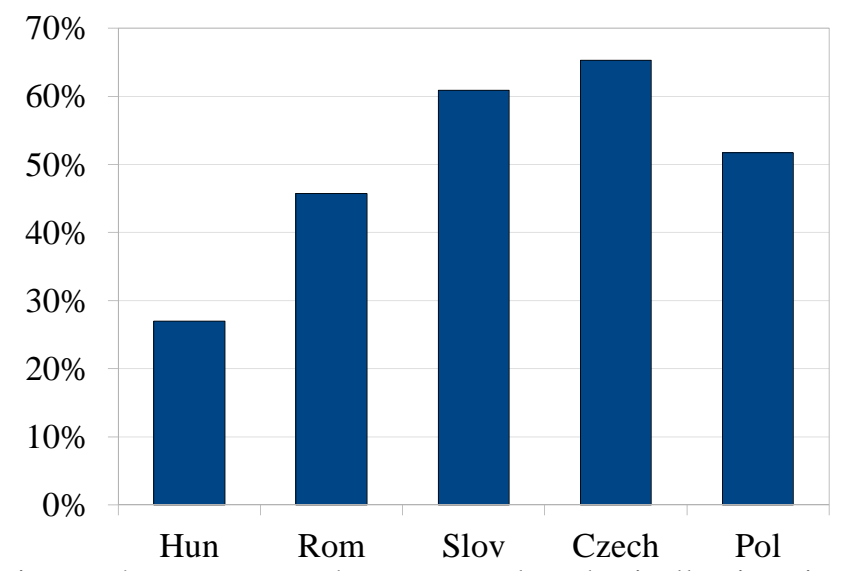

Figure 4. Young mothers currently physically inactive $(\mathrm{N}=336)$

Source: own study. with the optimal regularity. Their most favorite sports are jogging, swimming, aerobics, and yoga (Hungarians); jogging, walking, and yoga (Romanians and Slovakians); and yoga, jogging, and aerobics (Poles). With the Czech active mothers, the most frequently mentioned sport is yoga, which may explain the relatively high regularity.

\section{Frequency of back pain}

For the purpose of the analysis, back pain was divided between upper and lower back pain. Findings concerning the frequency of the pain painted the following picture. In Hungary $13.5 \%$ of the young mothers have upper back pain, while $16.2 \%$ of them have lower back pain frequently. In Romania, roughly one-third of the young mothers have upper back pain frequently, while lower back pain often causes problems for one-quarter of them. In Slovakia, twothirds of the young mothers regularly suffer from upper
The current sporting habits can also be characterized by considerable national differences. Roughly one-quarter of the Hungarian, about onehalf of the Romanian and the Polish, $60.9 \%$ of the Slovakian, and two-thirds of the Czech young mothers were totally inactive physically at the time of the data collection (Figure 4).

Similar differences could be observed in connection with the frequency of physical activity done weekly by active young mothers. The optimal frequency (two-three times a week) could be registered as follows: $44 \%$ of the Hungarian mothers, $28.4 \%$ of the Romanian mothers, $17.6 \%$ of the Slovakian mothers, $58.8 \%$ of the Czech mothers, and $35.7 \%$ of the Polish mothers do sport 
back pain, and three-fourths of them have to cope with lower back pain. In Czech Republic, upper back pain and low back pain occur in, respectively, $57.1 \%$ and in $69.4 \%$ of the young mothers. In Poland, about one-half of the young mothers suffer from upper back pain, while lower back pain causes regular problems for one-tenth of them. In Slovakia and Czech Republic, there were many more young mothers who suffered from different kinds of back pain than in the other countries involved in the investigation (Figure 6). This situation is surely related to the fact that the most working mothers can be found in these two countries; as a result, they are the less active in DOIng sport and exercise.

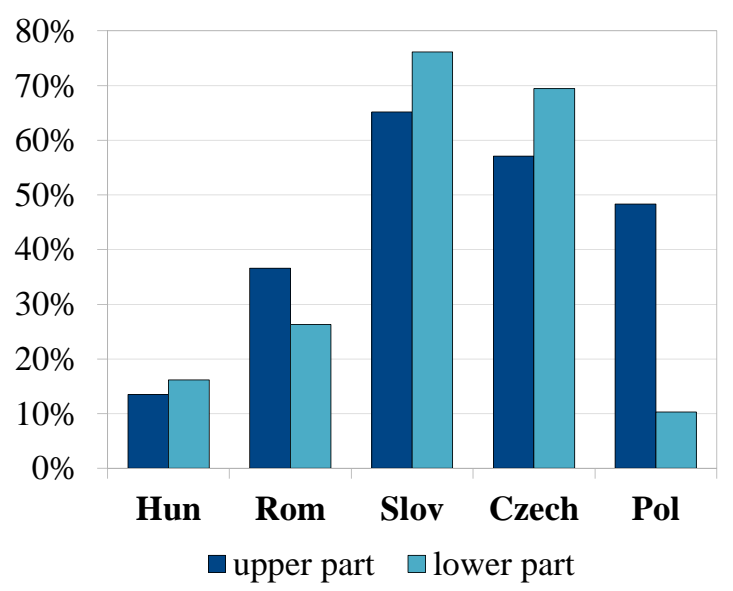

Figure 6. Frequency of back pains according to country $(\mathrm{N}=336)$

Source: own study.

\section{Restarting sporting activity and back pains}

We examined the length of the time period of the young mothers' inactivity after childbirth. The findings revealed that the longer the period of inactively that passed after the childbirth, the more frequently the young mothers had back pain. The data show that there is a significant correlation between the length of time before returning to physical activity after childbirth and pain both in the upper part $\left(X^{2}=14.439, \mathrm{df}=6\right.$, $\mathrm{p}=0.025)$ and the lower part $\left(X^{2}=15.711, \mathrm{df}=6, \mathrm{p}=0.015\right)$ of the back (Tables 2 and 3$)$.

Table 2. Length of time before returning to physical activity after childbirth and upper back pain

\begin{tabular}{llccccc}
\hline & & \multicolumn{2}{c}{$\begin{array}{c}\text { Length of time before returning to } \\
\text { physical activity after childbirth }\end{array}$} & \multicolumn{2}{c}{ Total } \\
& & $2-3$ months & 6 months & 9 months & not active & \\
\hline Upper back pain & never & 14 & 10 & 16 & 22 & 62 \\
& rarely & 27 & 25 & 22 & 59 & 133 \\
& frequently & 18 & 21 & 18 & 84 & 141 \\
& Total & 59 & 56 & 56 & 165 & 336 \\
\hline
\end{tabular}

Source: own study.

Table 3. Length of time before returning to physical activity after childbirth and low back pain

\begin{tabular}{llccccc}
\hline & & \multicolumn{2}{c}{$\begin{array}{c}\text { Length of time before returning to } \\
\text { physical activity after childbirth }\end{array}$} & \multicolumn{2}{c}{ Total } \\
& & $2-3$ months & 6 months & 9 months & not active & \\
\hline Low back pain & never & 23 & 14 & 19 & 35 & 91 \\
& rarely & 20 & 24 & 23 & 54 & 121 \\
& frequently & 16 & 18 & 14 & 76 & 124 \\
& Total & 59 & 56 & 56 & 165 & 336 \\
\hline
\end{tabular}

Source: own study.

\section{Conclusion}

One of the most frequent health problems for young mothers' after childbirth is the frequent occurrence of backaches. This is also a general problem among both women and men in contemporary societies due to sedentary lifestyles. In this paper, the relationship of young mothers' physical activity in their early years (aged 6-18 years), their physical activity in motherhood, and their record of back pain were analyzed on the basis of a cross-cultural comparative study.

Five post-communist countries were involved in the investigation where during the so-called socialist 
era, it was mainly the elite sport that was supported by the State, whereas mass sport and leisure sports were neglected. Although the research subjects were growing up and were socialized into sport after the political and economic regime changes that took place in Eastern Europe at the beginning of the 1990s, the results revealed that many sporting values, norms, and attitudes rooted in the previous political system survived the system change. These have had a serious impact on the sport-related behavior of the population, including young mothers. Some similarities between the young mothers with different nationalities originated from similar legacies in this context.

The proportion of the young mothers that had back pain more or less regularly was high in all five countries, especially if we take into consideration that the research subjects were college or university graduates who should have been aware of the significance of a physically active lifestyle. The reasons for this phenomenon are multifarious. There can be no doubt that early sport socialization plays a decisive role in this process. According to our findings, the correlation between sporting activity in the early years (aged 6-18 years) and engaging in physical activity in adulthood is strong; we can therefore state that physical activity begun in childhood can accompany someone more or less throughout the whole life cycle. Many more young mothers who were involved in sport and exercise in their childhood and youth began practicing again relatively soon after childbirth as compared to those who were never active physically in their youth. Furthermore, the results revealed that the latter had back pains significantly more often than the young mothers who practiced sports. These data suggest that back pains are not always an unavoidable consequence of childbirth; generally speaking, they can be prevented by simple means. Young women can be and should be informed about this advice partly in their school years, partly during their pregnancy.

It is another issue whether these simple means cannot be always used in an easy way. The question of whether sport and exercise are available for young mothers depends on the one hand on social policy concerning the length of maternity leave, access to nurseries, possibilities for working part-time, and on the other hand, the value system in connection with young mothers' role-concept, and with the division of labor in the family. Several differences between the young mothers' involvement in sport, and, as a result, between the frequency of their back pain, are rooted not in the past but in the present differences between the countries in question in this respect.

Of the decisive factors, one of the most practical ones is whether one breadwinner is sufficient for a family or not. Many young mothers return to work because they have no real choice: they start working soon after childbirth because their husband's salary is not high enough to support the family's cost of living. Perhaps even more young mothers would return to work sooner following childbirth if their neighborhoods were supplied with nurseries to a larger extent.

It should be added that some research subjects might have had the intention to return to work not necessarily for financial reasons but because they were intellectuals and had creative jobs. Or perhaps they returned to work because they were afraid of losing their job: legal protection for such situations, as an element of family policy, has been weakening.

In order to understand this phenomenon more deeply in the individual countries, further research is needed with the involvement of larger research populations. However, these data already may serve as warning signs for decision makers to pay more attention to preventive action, including the promotion of sport and exercise from childhood to motherhood, and to spread more information about possible ways to prevent back pain in young mothers.

\section{REFERENCES}

Bendíková, E., Dobay, B., Jancokova, L. (2011). Health and Physical Activity in the Life of the Slovakian Population. In G.F. Foldesi \& T. Dóczi (Eds.), The Interaction of Sport and Society in the V4 countries (pp. 111-113). Budapest: Hungarian Society of Sport Science.

Domnariu, C., Furtunescu, F. (2011). Intervention pattern regarding healthy nutrition and physical activity in Romania. Retrieved November 27, 2012, from http://www.amtsibiu.ro/Arhiva/2011/Nr1-en/Domnariu-en.pdf 
Egészségügyi Minisztérium /Ministry of Health Care/ (2009). Dohányzás- “Flash Eurobarometer a dohányzásról”/Smoking- "Flash Eurobarometer on smoking”/. Retrieved November 27, 2012, from http://www.eum.hu/ eu-egeszsegugy/hirek-eu-bol/dohanyzas-flash

Egészségügyi Stratégiai Kutatóintézet/Research Institute for Health Care Strategy/ (2006). Egészségügyi reformok Szlovákiában /Healthcare reforms in Slovakia/. Retrieved November 27, 2012, from http://www.eski.hu/ civiltajekoztatas/kepek/ho/anyagok/szlovakia-k.pdf

Egészségügyi Stratégiai Kutatóintézet/Research Institute for Health Care Strategy/ (2010). Tájékoztató országtanulmán /Country report/. Retrieved November 27, 2012, from http://www.eski.hu/civiltajekoztatas/kepek/ho/anyagok/ romania_2010.pdf

Egészségügyi Stratégiai Kutatóintézet/Research Institute for Health Care Strategy/ (2011) Tájékoztató országtanulmány Lengyelország egészségügyéröl/Country report on health care in Poland/. Retrieved November 27, 2012, from .http://vega.medinfo.hu/civiltajekoztatas/kepek/ho/anyagok/lengyelorszag_2011.pdf

Euvonal/Euline/ (2012): Családi támogatások/Family support/. Retrieved November 27, 2012, from http://www.euvonal.hu/index.php?op=mindennapok_tagallamok\&id=31\#8

http://www.euvonal.hu/index.php?op=mindennapok_tagallamok\&id=25\#12

http://www.euvonal.hu/index.php?op=mindennapok_tagallamok\&id=20\#7

http://www.euvonal.hu/index.php?op=mindennapok_tagallamok\&id=22\#4

Foldesi, G.F. (1993). The Transformation of Sport in Eastern Europe: The Hungarian Case. Journal of Comparative Physical Education and Sport, XV, 1, 5-21.

Foldesi, G.F. (2011). What does Hungarian Sport Expect from Society Rightly or Wrongly? In G.F. Foldesi \& T. Dóczi (Eds.), The Interaction of Sport and Society in the V4 countries (pp. 49-64). Budapest: Hungarian Society of Sport Science.

Gal, A. (2003). Nők formában?/Women in shape?/. In F.G. Foldesi \& A. Gal, Sport és társadalom /Sport and Society/ (pp. 145-154). Budapest: Magyar Sporttudományi Társaság/Hungarian Society of Sport Science.

Gal, A. (2008). A magyar lakosság egészségtudatossága és szabadidő-sportolási szokásai/The Hungarian population’s health consciousness and its customs related to leisure sport/. In G.F. Foldesi, A Gal \& T. Dóczi (Eds.), Társadalmi riport a sportról /Social report on sport/ (pp. 9-39). Budapest: Magyar Sporttudományi Társaság/ Hungarian Society of Sport Science.

Gal, A. (2011). Society and sport in Hungary: Neither with nor without. In G.F. Foldesi \& T. Dóczi (Eds.), The Interaction of Sport and Society in the V4 countries (pp. 65-83). Budapest: Hungarian Society of Sport Science.

Global Finance (2012). Country Economic Reports \& GDP Data. Retrieved November 27, 2012, from http://www.gfmag.com/gdp-data-country-reports.html\#axzz2DQ1XTmVM

Jeney, L. (2008). A szomszédsági hasonlóság szerepe az Európai Unió nagyvárosai közötti fejlettségi különbségekben The role of neighborhood-based similarities in the differences in the level of development between the big cities in the European Union/. Retrieved November 27, 2012, from http://www.ksh.hu/docs/hun/xftp/terstat/2008/terstat0801.pdf

Kobiela, F. (2011). From State Socialism to Free Society: Sport in Poland from 1945 until Present Day. In G.F. Foldesi \& T. Dóczi (Eds.), The Interaction of Sport and Society in the V4 countries (pp. 85-93). Budapest: Hungarian Society of Sport Science.

Murtezani, A., Ibraimi, Z., Sllamniku, S., Teuta, O., Sherifi, S. (2011). Prevalence and risk factors for low back pain in industrial workers. Folia Medica, 53(3), 70.

Sekot, A. (2011a). Sport as a Form of Public Well-being in the Czech Republic. In G.F. Foldesi \& T. Dóczi (Eds.), The Interaction of Sport and Society in the V4 countries (pp. 11-33). Budapest: Hungarian Society of Sport Science.

Sekot, A. (2011b). Lifestyle and Living Physical Activity as a Part of an Active Way of Life in the Czech Republic. Physical Culture and Sport. Studies and Research. 53(1), 48-64. DOI: 10.2478/v10141-011-0022-8.

Slepicková, I. (2011). New Space for a New Face of Sport in Central and Eastern European Countries. In G.F. Foldesi \& T. Dóczi (Eds.), The Interaction of Sport and Society in the V4 countries (pp. 25-48). Budapest: Hungarian Society of Sport Science.

Special Eurobarometer (2007). Health in the European Union. Retrieved November 27, 2012, from http://ec.europa.eu/ health/ph_publication/eb_health_en.pdf

Rymarczyk, P. (2011). What Does Polish Society Expect from Sport? In G.F. Foldesi \& T. Doczi (Eds.), The Interaction of Sport and Society in the V4 countries (pp. 95-103). Budapest: Hungarian Society of Sport Science.

Toldy, A. (2009). A sport célja, feladata korosztályonként/The purpose and the task of sport by age group. In T. Szatmári (Ed.), Sport, életmód egészség /Sport, way of life, health/(pp.632-633). Budapest: Akadémiai Kiadó. 
AUTHOR'S ADDRESS: Barbara Abonyi

Faculty of Physical Education and Sport Sciences

Semmelweis University

Alkotás utca 44

1123 Budapest, Hungary

Email: abonyibarbara21@gmail.com 